\title{
UPAYA MENINGKATKAN HASIL BELAJAR SISWA DENGAN \\ MODEL PEMBELAJARAN PROBLEM BASED INSTRUCTION (PBI) PADA POKOK BAHASAN PERBANDINGAN DI KELAS VIII C SMP R. RAHMAT BALONGBENDO SIDOARJO
}

\author{
Mohammad Sony Bahrudin \\ Prodi Pendidikan Matematika FKIP UMSurabaya \\ semarbadrun@yahoo.co.id
}

\begin{abstract}
ABSTRAK
Salah satu faktor yang mempengaruhi hasil belajar siswa adalah model pembelajaran yang diterapkan dalam proses pembelajaran. Banyak model pembelajaran tetapi ada salah satu model pembelajaran yang baik dan tepat untuk diterapkan yakni model pembelajaran yang menekankan aktivitas siswa untuk belajar dan mengarah pada permasalahan kehidupan sehari-hari sehingga dapat dimengerti oleh siswa, model pembelajaran problem based instruction. Jenis penelitian tindakan kelas dengan subjek penelitian siswa kelas VIIIC SMP R. Rahmat Balongbendo Sidoarjo Tahun Pelajaran 2014/2015. Penelitian dilaksanakan dua siklus tindakan. Untuk mengetahui hasil belajar siswa menggunakan teknik pengumpulan data metode tes, metode observasi. Hasil penelitian menunjukkan bahwa hasil belajar matematika siswa kelas VIIIC SMP R. Rahmat Balongbendo Sidoarjo mengalami peningkatan. Data awal sebelum tindakan nilai UTS Genap 48,57\% setelah diterapkannya model pembelajaran pada aspek kognitif siklus I 54,29\% tuntas setelah dilakukan siklus II meningkat menjadi $100 \%$ tuntas. Peningkatan aktivitas siswa aspek afektif $73,10 \%$ pada siklus I setelah dilakukan siklus II meningkat menjadi $80,65 \%$. Peningkatan aktivitas siswa aspek psikomotor $70,86 \%$ pada siklus I setelah dilakukan siklus II meningkat menjadi $80,76 \%$.
\end{abstract}

Kata kunci: hasil belajar; problem based instruction.

\section{PENDAHULUAN}

Salah satu faktor yang berpengaruh dalam hasi belajar siswa dalam pembelajaran yakni model pembelajaran yang dilaksanakan guru. Beberapa guru hanya melaksanakan kegiatan belajar mengajar dengan satu model yang kebetulan tidak sesuai atau bersifat tidak menerapkan konsep. Guru mengajar hanya menyampaikan konsep dan materi kepada siswa sehingga kenyataan dilapangan siswa hanya menghafal pada saat siswa diberikan suatu persoalan yang berkenaan dengan permasalahan kehidupan sehari-hari siswa tidak dapat memecahkan masalah tersebut. Hal ini menyebabkan rendahnya minat siswa untuk mengikuti pelajaran dengan baik dan bersungguh-sungguh karena pembelajaran yang dilaksanakan kurang menarik dan kurang melibatkan siswa secara aktif dalam belajar. Pembelajaran yang kurang melibatkan siswa secara aktif dalam belajar 


\section{Mohammad Sony Bahrudin}

dapat menghambat kemampuan belajar matematika siswa dalam pemecahan masalah. Pemilihan model pembelajaran yang tepat sangat penting untuk tercapainya tujuan pembelajaran matematika. Pembelajaran yang baik adalah pembelajaran yang dapat meningkatkan minat dan respon siswa dan dikaitkan dengan gejala fenomena kehidupan sehari-hari sehingga siswa dapat mengerti dan paham suatu konsep secara nyata. Arends dalam Trianto (2007: 68), Pembelajaran berdasarkan masalah merupakan suatu pendekatan pembelajaran dimana siswa mengerjakan permasalahan yang otentik dengan maksud untuk menyusun pengetahuan mereka sendiri, mengembangkan inkuiri dan keterampilan berpikir tingkat lebih tinggi, mengembangkan kemandirian dan percaya diri. Model pembelajaran ini juga mengacu pada model pembelajaran yang lain, seperti "pembelajaran berdasarkan proyek (project-based instruction)", pembelajaran berdasarkan pengalaman (experience-based instruction)", belajar otentik (authentic learning)" dan pembelajaran bermakna ( anchored instruction )".

Jadi model pembelajaran berdasarkan masalah lebih mengarah kepada siswa untuk aktif dalam proses pembelajaran dan guru sebagai fasilitator atau pendorong siswa untuk lebih aktif. Guru memberikan stimulus berupa pertanyaan yang berkaitan dengan permasalahan kehidupan sehari-hari sehingga konsep yang dipelajari dapat diterapkan dengan nyata. Siswa dituntut untuk menganalisis dan mendefinisikan masalah, mengembangkan hipotesis, membuat ramalan, mengumpulkan dan menganalisa informasi, serta menyimpulkan pendapat dari awal kegiatan pembelajaran.

Salah satu model pembelajaran yang dapat meningkatkan hasil belajar dalam aspek kognitif, minat dan respon siswa dalam menyelesaikan permasalahan kehidupan sehari-hari yaitu model pembelajaran problem based instruction. Model pembelajaran berdasarkan masalah lebih menekankan aktivitas siswa untuk belajar dan permasalahan pada materi lebih diarahkan pada kehidupan sehari-hari sehingga secara langsung dapat dimengerti oleh siswa.

Dari uraian diatas, maka peneliti mengambil judul "Upaya Meningkatkan Hasil Belajar Siswa dengan Model Pembelajaran Problem Based Instruction (PBI) pada Pokok Bahasan Perbandingan di Kelas VIII C SMP R. Rahmat Balongbendo Sidoarjo". 


\section{METODE PENELITIAN}

Penelitian ini merupakan penelitian tindakan kelas (PTK). Penelitian ini lebih mengarah untuk memperbaiki kondisi kelas dimana terjalin interaksi antara guru dan siswa dalam proses pembelajaran. Secara garis besar model penelitian tindakan kelas meliputi empat hal pokok menurut Arikunto (2011:16) yakni: (1) perencanaan, (2) pelaksanaan, (3) pengamatan, dan (4) refleksi.

Pada tahap perencanaan peneliti membuat serta mengembangkan perangkat pembelajaran dan instrumen pembelajaran. Kemudian dilanjutkan dengan tahap pelaksanaan pembelajaran diikuti dengan pengamatan kegiatan pembelajaran yang berlangsung secara bersama-sama. Pada tahap akhir refleksi peneliti menganalisa atau mengelolah data dari pelaksanaan penelitian yang dilaksanakan serta membahas kekurangan dan kelebihan dari penerapan model pembelajaran yang terlaksana. Apabila siklus awal diketahui penerapan model pembelajaran keberhasilan lebih kecil dan besarnya hambatan atau permasalahan lebih rumit maka tindakan yang telah dilaksanakan dalam siklus awal, guru pelaksana (bersama peneliti) melaksanakan siklus kedua. Penelitian tindakan kelas ini dikatakan berhasil jika hasil belajar siswa telah mencapai indikator keberhasilan yaitu 71 tuntas dari kriteria ketuntasan minimal. Penelitian tindakan kelas ini berlangsung dua siklus. Jika hasil penelitian ini tidak mencapai indikator keberhasilan maka guru mata pelajaran akan melanjutkan pada siklus ketiga di luar penelitian.

Penelitian ini dilaksanakan di SMP R. Rahmat Balongbendo Sidoarjo. Gedung R. Rahmat berlokasi di desa Bakalanwringinpitu kecamatan Balongbendo Kab. Sidoarjo. Subjek penelitian ini adalah siswa kelas VIIIC SMP R. Rahmat Balongbendo Sidoarjo yang terdiri dari 35 yang terdiri dari 20 siswa laki-laki dan 15 siswa perempuan.

Teknik pengumpulan data pada penelitian adalah metode tes dan metode observasi. Analisis data penelitian ini meliputi hasil belajar siswa. Analisis data dilakukan dengan mengacu pada analisis data kuantitatif menurut Arikunto (2008:236). 
Menurut hasil penelitian yang dilakukan oleh Hidayat (2012) yang berjudul "Penerapan Model Pembelajaran Arias Terintegrasi pada Pembelajaran Problem Based Instruction untuk Meningkatkan Motivasi Dan Hasil Belajar matematika Kelas XI IPA 1 Semester II SMA Muhammadiyah 2 Gemolong”. Hasil penelitiannya menunjukkan adanya peningkatan motivasi siswa dalam pembelajaran dan hasil belajar siswa yang mencapai standar KKM.

\section{HASIL PENELITIAN DAN PEMBAHASAN}

Hasil observasi kegiatan guru selama siklus I dan siklus II pada pertemuan 1,2,3 dan 4. dapat dilihat pada Tabel 1 berikut:

Tabel 1: Data Penilaian Aktivitas Guru Siklus I

\begin{tabular}{|c|c|c|}
\hline \multirow{3}{*}{ Aspek yang diamati } & Siklus I & Siklus II \\
\hline & RPP I \& II & RPP III \& IV \\
\hline & Skor & Skor \\
\hline A. Pendahuluan & 34 & 37 \\
\hline B. Inti & 153 & 155 \\
\hline C. Penutup & 13 & 12 \\
\hline Jumlah & 200 & 204 \\
\hline Prosentase & $78,13 \%$ & $79,69 \%$ \\
\hline Skala Empat & 3,13 & 3,19 \\
\hline
\end{tabular}

Berdasarkan tabel di atas diketahui bahwa pada RPP I dan RPP II siklus I kemampuan guru dalam mengelola pembelajaran memperoleh skor 200 dengan prosentase $78,13 \%$ dengan kriteria baik. Hal ini berarti sudah memenuhi kriteria indikator keberhasilan penelitian yaitu pada kategori baik. pada RPP III dan RPP IV pada siklus II kemampuan guru dalam mengelola pembelajaran memperoleh skor 204 dengan prosentase 79,69\% dengan kriteria baik.

Hasil observasi aktivitas siswa selama siklus I dan siklus II pada pertemuan 1,2,3 dan 4. dapat dilihat pada Tabel 2 berikut:

Tabel 2: Observasi Aktivitas Siswa

\begin{tabular}{|c|c|c|c|c|c|c|c|c|}
\hline \multirow[b]{2}{*}{ Aspek } & \multicolumn{2}{|c|}{ Kriteria } & \multicolumn{3}{|c|}{ Siklus I } & \multicolumn{3}{|c|}{ Siklus II } \\
\hline & $\begin{array}{c}\text { Rentang } \\
\text { Nilai } \\
\end{array}$ & Huruf & $\begin{array}{c}\text { Banyak } \\
\text { Siswa } \\
\end{array}$ & Ket & Persen & $\begin{array}{c}\text { Banyak } \\
\text { Siswa } \\
\end{array}$ & Ket & Persen \\
\hline \multirow{5}{*}{$\begin{array}{c}\mathbf{P} \\
\mathbf{S} \\
\mathbf{I} \\
\mathbf{K} \\
\mathbf{O} \\
\mathbf{M}\end{array}$} & $3,51-3,84$ & A- & & & & 2 & Sangat Baik & $5,71 \%$ \\
\hline & $3,18-3,50$ & $\mathrm{~B}+$ & 10 & Baik & $28,57 \%$ & 19 & Baik & $54,29 \%$ \\
\hline & $2,85-3,17$ & $\mathrm{~B}$ & 7 & Baik & $20,00 \%$ & 14 & Baik & $40,00 \%$ \\
\hline & $2,51-2,84$ & B- & 10 & Baik & $28,57 \%$ & & & \\
\hline & $2,18-2,50$ & $\mathrm{C}+$ & 8 & Cukup & $22,86 \%$ & & & \\
\hline
\end{tabular}


Upaya Meningkatkan Hasil Belajar Siswa Dengan Model Pembelajaran Problem Based Instruction

\begin{tabular}{|c|c|c|c|c|c|c|c|c|}
\hline \multirow[b]{2}{*}{ Aspek } & \multicolumn{2}{|c|}{ Kriteria } & \multicolumn{3}{|c|}{ Siklus I } & \multicolumn{3}{|c|}{ Siklus II } \\
\hline & $\begin{array}{c}\text { Rentang } \\
\text { Nilai }\end{array}$ & Huruf & $\begin{array}{c}\text { Banyak } \\
\text { Siswa }\end{array}$ & Ket & Persen & $\begin{array}{c}\text { Banyak } \\
\text { Siswa }\end{array}$ & Ket & Persen \\
\hline \multirow{4}{*}{$\begin{array}{l}\mathbf{O} \\
\mathbf{T} \\
\mathbf{O} \\
\mathbf{R}\end{array}$} & $1,85-2,17$ & $\mathrm{C}$ & & & & & & \\
\hline & $1,51-1,84$ & C- & & & & & & \\
\hline & $1,18-1,50$ & D+ & & & & & & \\
\hline & $1,00-1,17$ & $\mathrm{D}$ & & & & & & \\
\hline \multirow{10}{*}{$\begin{array}{l}\mathbf{A} \\
\mathbf{F} \\
\mathbf{E} \\
\mathbf{K} \\
\mathbf{T} \\
\mathbf{I} \\
\mathbf{F}\end{array}$} & $3,85-4,00$ & A & & & & & & \\
\hline & $3,51-3,84$ & A- & & & & 3 & Sangat baik & $8,57 \%$ \\
\hline & $3,18-3,50$ & $\mathrm{~B}+$ & 4 & Baik & $11,43 \%$ & 15 & Baik & $42,86 \%$ \\
\hline & $2,85-3,17$ & B & 15 & Baik & $42,86 \%$ & 17 & Baik & $48,57 \%$ \\
\hline & $2,51-2,84$ & B- & 15 & Baik & $42,86 \%$ & & & \\
\hline & $2,18-2,50$ & $\mathrm{C}+$ & 1 & Cukup & $2,86 \%$ & & & \\
\hline & $1,85-2,17$ & $\mathrm{C}$ & & & & & & \\
\hline & $1,51-1,84$ & C- & & & & & & \\
\hline & $1,18-1,50$ & $\mathrm{D}+$ & & & & & & \\
\hline & $1,00-1,50$ & $\mathrm{D}$ & & & & & & \\
\hline
\end{tabular}

Dari siklus I ke siklus II Aktivitas Siswa mengalami kenaikan yakni aspek psikomotor siklus I 77,14\% dengan kriteria baik, 22,86\% dengan kriteria cukup. Pada siklus II mengalami peningkatan dengan prosentase aspek psikomotor 5,71\% dengan kriteria sangat baik, 94,29\% dengan kriteria baik. Aspek afektif siklus I 97,15 dengan kriteria baik, 2,86\% dengan kriteria cukup. Pada siklus II mengalami peningkatan dengan prosentase aspek afektif 8,57\% dengan kriteria sangat baik, 91,43\% dengan kriteria baik. Perbandingan hasil tes evaluasi siklus I dengan siklus II mengalami peningkatan berikut disajikan dalam Tabel 3.

Tabel 3: Data Rekapitulasi Hasil Evaluasi Siklus I dan Siklus II

\begin{tabular}{|c|c|c|c|c|c|c|}
\hline \multirow{2}{*}{ Kriteria } & \multicolumn{2}{|c|}{ UTS Genap } & \multicolumn{2}{c|}{ Siklus I } & \multicolumn{2}{c|}{ Siklus II } \\
\cline { 2 - 7 } & $\begin{array}{c}\text { Banyak } \\
\text { Siswa }\end{array}$ & Persentase & $\begin{array}{c}\text { Banyak } \\
\text { Siswa }\end{array}$ & Persentase & $\begin{array}{c}\text { Banyak } \\
\text { Siswa }\end{array}$ & Persentase \\
\hline $\begin{array}{c}\text { Nilai } \\
\geq 2,85\end{array}$ & 17 & $48,57 \%$ & 19 & $54,29 \%$ & 35 & $100 \%$ \\
\hline $\begin{array}{c}\text { Nilai } \\
<2,85\end{array}$ & 18 & $51,43 \%$ & 16 & $45,71 \%$ & 0 & $0 \%$ \\
\hline Rata-rata & \multicolumn{2}{|c|}{2,75} & \multicolumn{2}{|c|}{3,01} & \multicolumn{2}{c|}{3,37} \\
\hline $\begin{array}{c}\text { Standar } \\
\text { Deviasi }\end{array}$ & \multicolumn{2}{|c|}{11,23} & \multicolumn{2}{|c|}{12,05} & \multicolumn{2}{c|}{6,80} \\
\hline Tertinggi & \multicolumn{2}{|c|}{3,52} & \multicolumn{2}{c|}{3,76} & \multicolumn{2}{c|}{3,76} \\
\hline
\end{tabular}




\begin{tabular}{|l|l|l|l|}
\hline Terendah & 1,44 & 2,00 & 2,96 \\
\hline
\end{tabular}

Berdasarkan Tabel 3 pelaksanaan siklus II mengalami peningkatan dengan ketuntasan $100 \%$. pada siklus I nilai terendah 50 dalam skala empat 2,00 dan nilai tertinggi 94 dalam skala empat 3,76 rata-rata ketuntasan 54,29\%. Pada siklus II terjadi peningkatan dengan nilai terendah 74 dalam skala empat 2,96 dan nilai tertinggi 94 dalam skala empat 3,76 rata-rata ketuntasan $100 \%$ pada siklus II sehingga siklus dihentikan karena sudah mencapai indikator ketuntasan.

Data awal sebelum tindakan peneliti diambil dari data Ujian Tengah Semester Genap tahun ajaran 2014/2015. Pembelajaran ini dilakukan oleh guru sedangkan peneliti sebagai pengamat.

Adapun uraian pelaksanaan pembelajaran adalah sebagai berikut:

Tahap Perencanaan

Pada tahap ini dilakukan langkah-langkah:

1. Menentukan pokok bahasan yang akan diajarkan

2. Menyiapkan Rencana Pelaksanaan Pembelajaran (RPP)

3. Menyiapkan lembar observasi aktivitas guru

4. Menyiapkan Lembar Kerja Siswa (LKS)

5. Menyiapkan lembar observasi aktivitas siswa

6. Menyiapkan soal tes evaluasi untuk siklus I

Tahap Pelaksanaan Tindakan

Pertemuan Pertama (RPP 1)

1. Pembukaan

a. Memberi salam dan seluruh siswa hadir, yaitu sejumlah 35 siswa.

b. Guru menyampaikan tujuan pembelajaran.

c. Guru memberi apersepsi.

d. Mengingat kembali tentang perbandingan Guru memberi motivasi dengan mengajukan pertanyaan.

e. Guru memberi petunjuk pelaksanaan pembelajaran dengan mengajukan atau memunculkan masalah. 
f. Guru membagi siswa menjadi 5 kelompok yang terdiri dari 7 siswa secara heterogen.

2. Kegiatan inti

a. Siswa diberikan motivasi untuk terlibat dalam pemecahan masalah yang dipilih.

b. Memberikan LKS membantu siswa untuk mendefinisikan dan mengorganisasikan tugas belajar yang berhubungan dengan masalah tersebut.

c. Menyajikan hasil dan guru merespon siswa jika mengalami kesulitan.

d. Guru meminta tiap perwakilan kelompok untuk mempresentasikan hasil diskusi. Kelompok lain memberi tanggapan.

e. Guru memberi kesempatan pada siswa yang belum mengerti untuk bertanya.

\section{Kegiatan Akhir}

a. Guru dan siswa menyimpulkan materi sesuai tujuan pembelajaran.

b. Guru memberi pekerjaan rumah

Berdasarkan ketuntasan belajar setelah dilakukan tindakan mengalami beberapa kenaikan dan nilai rata-rata juga naik. Tetapi pada siklus I belum sampai mencapai ketuntasan ada beberapa siswa yang nilai hasil evaluasi belajarnya dibawah KKM, berdasarkan hasil observasi ada beberapa faktor yang menyebabkan pelaksanaan siklus I kurang maksimal yakni, masih terbiasa dengan pembelajaran langsung, siswa belum terbiasa melaksanakan tugas berkelompok sehingga terjadi keramaian pada saat pembelajaran berlangsung, ada siswa yang berjalan-jalan ke kelompok lain, siswa masih terlihat malas dan enggan mencoba. Kelompok siswa bagian belakang ada yang hanya memperhatikan LKS dan tidak berusaha untuk mengerjakan hanya mengandalkan teman kelompoknya. Setelah didekati oleh guru baru siswa mulai mengerjakan tetapi masih dengan bimbingan guru. Pada saat presentasi kelompok maju kedepan beberapa kelompok masih malu untuk mempresentasikan hasil diskusinya. Sehingga guru membantu siswa 
dalam melaksanakan presentasi didepan kelas. Semua hasil observasi siklus I dicatat dalam lembar observasi dengan hasil sebagai berikut pada Siklus I:

1. 80,47\% langkah-langkah pembelajaran PBI terlaksana pada akhir siklus I.

2. Total aktivitas psikomotor siswa $77,14 \%$ dengan kriteria baik, 22,86 \% siswa memperoleh kriteria cukup.

3. Total aktivitas afektif siswa sebesar 97,14\% siswa memperoleh kriteria baik dan 2,86\% siswa memperoleh kriteria cukup.

Sedangkan melihat rekapitulasi hasil evaluasi Siklus I pada Tabel 4 beberapa siswa yang mendapatkan nilai mendekati sempurna yaitu 3,76. Hasil tersebut dapat disimpulkan ada yang memiliki antusias dalam mengikuti kegiatan pembelajaran tetapi ada juga beberapa siswa yang hasil tes evaluasi dibawah kriteria ketuntasan minimal sehingga perlu dilakukan pembelajaran unntuk siklus II. Semua hasil observasi siklus II dicatat dalam lembar observasi dengan hasil sebagai berikut pada Siklus II

1. 81,25\% langkah-langkah pembelajaran PBI terlaksana pada akhir siklus I.

2. Pada aspek psikomotor sebesar 5,71\% siswa memperoleh kriteria sangat baik dan 94,29\% siswa memperoleh kriteria baik.

3. Pada aspek afektif sebesar $8,57 \%$ siswa memperoleh kriteria sangat baik dan sebesar 91,43\% siswa memperoleh kriteria baik.

Berdasarkan data hasil observasi aktivitas guru melaksanakan pembelajaran dan, data hasil belajar siswa pada siklus II dapat diperoleh kesimpulan sebagai berikut:

1. Waktu yang digunakan guru dalam mengawali pembelajaran, menjelaskan materi, memberikan latihan terbimbing serta tugas mandiri cukup memadai sehingga proses pembelajaran dapat berjalan sesuai dengan rencana.

2. Kegiatan pembelajaran berjalan dengan baik karena memberikan peluang bertanya kepada siswa yang belum bertanya pada siklus I setelah itu memberikan kesempatan kepada siswa yang aktif bertanya, siswa berani bertanya kepada guru, siswa dapat beradaptasi dalam berkelompok. Siswa mulai berani melakukan presentasi didepan kelas.

3. Dari data hasil observasi siswa menunjukkan bahwa peran siswa dalam kegiatan pembelajaran berperan aktif. 


\section{SIMPULAN}

Berdasarkan pembahasan diatas dapat disimpulkan terjadi peningkatan proses dan kegiatan pembelajaran dengan menggunakan model pembelajaran atau problem based instruction yang ditunjukkan sebagai berikut:

1. Pelaksanaan pembelajaran dengan model pembelajaran Problem based instruction (PBI) mempunyai kategori baik dengan prosentase $81,25 \%$ pada akhir siklus II dengan kriteria skala empat yakni 3,25 sehingga dapat ditarik kesimpulan bahwa penelitian aktivitas guru melaksanakan pembelajaran dengan kriteria baik.

2. Hasil belajar siswa dengan model pembelajaran problem based instruction (PBI) meningkat dengan baik yang meliputi tiga aspek yakni aspek psikomotor siklus I 77,14\% dengan kriteria baik, 22,86\% dengan kriteria cukup. Pada siklus II mengalami peningkatan dengan prosentase aspek psikomotor 5,71\% dengan kriteria sangat baik, 94,29\% dengan kriteria baik. Aspek afektif siklus I 97,15 dengan kriteria baik, 2,86\% dengan kriteria cukup. Pada siklus II mengalami peningkatan dengan prosentase aspek afektif 8,57\% dengan kriteria sangat baik, 91,43\% dengan kriteria baik.

Rata-rata skor tes kemampuan tes evaluasi matematika siswa pada akhir siklus terjadi peningkatan dan memenuhi standar ketuntasan belajar KKM yakni $\geq 71$ yakni pada siklus I nilai terendah 50 dalam skala empat 2,00 dan nilai tertinggi 94 dalam skala empat 3,76 rata-rata ketuntasan 54,29\%. Pada siklus II terjadi peningkatan dengan nilai terendah 74 dalam skala empat 2,96 dan nilai tertinggi 94 dalam skala empat 3,76 rata-rata ketuntasan $100 \%$ pada siklus II.

\section{DAFTAR PUSTAKA}

Arikunto, dkk. 2011. Penelitian Tindakan Kelas. Jakarta: Bumi Aksara.

Hidayat, M. Adityo. 2012. Penerapan Model Pembelajaran Arias Terintegrasi pada Pembelajaran Problem Based Instruction untuk Meningkatkan Motivasi Dan Hasil Belajar matematika Kelas XI IPA 1 Semester II SMA 
Muhammadiyah 2 Gemolong. (Skripsi). Surakarta: Universitas Muhammadiyah diakses 7 Maret 2015.

Trianto, 2007. Model-model Pembelajaran Inovatif Berorientasi Konstruktivistik. Jakarta: Prestasi Pustaka. 